\title{
Hormonal regulation of the hypothalamic melanocortin system
}

\author{
Jung D. Kim ${ }^{1,2}$, Stephanie Leyva ${ }^{1,2}$ and Sabrina Diano ${ }^{1,2,3,4 *}$ \\ ${ }^{1}$ Departments of Obstetrics, Gynecology and Reproductive Sciences, Yale University School of Medicine, New Haven, CT, USA \\ 2 Program in Cell Signaling and Neurobiology of Metabolism, Yale University School of Medicine, New Haven, CT, USA \\ ${ }^{3}$ Department of Neurobiology, Yale University School of Medicine, New Haven, CT, USA \\ ${ }^{4}$ Section of Comparative Medicine, Yale University School of Medicine, New Haven, CT, USA
}

\section{Edited by:}

Antonia Lanni, Second University of

Naples, Italy

Reviewed by:

Ursula H. Winzer-Serhan, Texas A\&M Health Science Center, USA

Virginie Tolle, Institut National de la

Santé et de la Recherche Médicale,

France

\section{*Correspondence:}

Sabrina Diano, Departments of

Obstetrics, Gynecology and

Reproductive Sciences, Yale

University School of Medicine, FMB

302A/333 Cedar Street, PO Box

208063, New Haven, CT

06520-208063, USA

e-mail: sabrina.diano@yale.edu
Regulation of energy homeostasis is fundamental for life. In animal species and humans, the Central Nervous System (CNS) plays a critical role in such regulation by integrating peripheral signals and modulating behavior and the activity of peripheral organs. A precise interplay between CNS and peripheral signals is necessary for the regulation of food intake and energy expenditure in the maintenance of energy balance. Within the CNS, the hypothalamus is a critical center for monitoring, processing and responding to peripheral signals, including hormones such as ghrelin, leptin, and insulin. Once in the brain, peripheral signals regulate neuronal systems involved in the modulation of energy homeostasis. The main hypothalamic neuronal circuit in the regulation of energy metabolism is the melanocortin system. This review will give a summary of the most recent discoveries on the hormonal regulation of the hypothalamic melanocortin system in the control of energy homeostasis.

Keywords: hypothalamic melanocortin system, arcuate nucleus, pro-opiomelanocortin (POMC), neuropeptide $Y$ (NPY), agouti-related peptide (AgRP), hormones, obesity

\section{HYPOTHALAMIC MELANOCORTIN SYSTEM}

Energy homeostasis is a tightly regulated process and the imbalance between its components, food intake and energy expenditure, causes metabolic dysfunctions including obesity, a major risk factor for comorbidities including type 2 diabetes, hypertension and stroke, and cardiovascular diseases. A major player in the regulation of energy homeostasis is the Central Nervous System (CNS) and specifically the hypothalamus. By monitoring, processing and responding to peripheral signals, such as hormones, the hypothalamus in turn will regulate peripheral organ functions. Within the hypothalamus several neuronal populations have been identified as important players in metabolism regulation. The central melanocortin system consists of three neuronal populations: the pro-opiomelanocortin (POMC)-expressing neurons, the neuropeptide Y (NPY) and agouti-related peptide (AgRP)-co-expressing neurons (Cowley et al., 1999; Elmquist et al., 1999) located in the hypothalamic arcuate nucleus and the melanocortin 4 receptor (MC4R)expressing neurons located in the hypothalamic paraventricular nucleus. While the anorexigenic POMC neurons, by activating MC4R neurons, induce decreased food intake and increased energy expenditure, the orexigenic NPY/AgRP neurons, by antagonizing POMC action on MC4R, increase food intake and decrease energy expenditure, thus increasing body weight.

The POMC gene encodes a protein precursor that generates a number of bioactive peptides, including adrenocorticotrophin (ACTH), $\alpha-, \beta$-, and $\gamma$-melanocyte stimulating hormone $(\alpha-$ $\mathrm{MSH}, \beta-\mathrm{MSH}$, and $\gamma$-MSH) and $\beta$-endorphin, via several post-translational modification processes. Among these peptides,
$\alpha$-MSH is the most well-known anorexigenic peptide which mediates the effects on food intake and energy expenditure through its binding and activation of MCRs (Ollmann et al., 1997).

The critical role of POMC in the regulation of metabolism has been evidenced by studies showing that in humans, individuals with POMC gene mutations display early-onset obesity (Krude et al., 1998; Krude and Gruters, 2000). A similar obese phenotype occurs also in POMC-deficient mice (Yaswen et al., 1999). However, while the acute ablation of POMC neurons in adult mice results in an obese phenotype with hyperphagia (Gropp et al., 2005), postnatal ablation of POMC neurons leads to an obese phenotype with reduced energy expenditure but no hyperphagia (Greenman et al., 2013). On the other hand, reactivation of central POMC at different stages of development in neuralspecific POMC deficient mice reduces food intake and weight gain and attenuates comorbidities such as hyperglycemia and hyperinsulinemia (Bumaschny et al., 2012).

Contrary to POMC mutations, NPY, and AgRP gene mutations produce a negligible phenotype with no difference in food intake and body weight (Erickson et al., 1996; Qian et al., 2002; Gropp et al., 2005; Luquet et al., 2005), suggesting that compensatory mechanisms may occur during development (Wu and Palmiter, 2011). Indeed, with the use of the diphtheria toxin and diphtheria toxin receptor (DTR)-mediated cell specific knockout system (Saito et al., 2001), acute ablation of AgRP neurons in adult mice causes a significant metabolic effect (Gropp et al., 2005; Luquet et al., 2005). Because these neurons also produce and release the inhibitory amino acid neurotransmitter, 
$\gamma$-aminobutyric acid (GABA), its role in the development of this metabolic phenotype regulation has been postulated. Indeed, AgRP-specific vesicular GABA transporter knockout mice have a lean phenotype and are resistant to high fat diet-induced obesity (Tong et al., 2008). GABAergic signaling by NPY/AgRP neurons inhibits POMC neurons in the ARC by direct synaptic innervations (Horvath et al., 1997; Cowley et al., 2001) and also inhibits the parabrachial nucleus (PBN) in the hindbrain (Wu et al., 2009). Moreover, the direct delivery of bretazenil (a GABA receptor partial agonist) into the PBN prevented anorexia caused by AgRP neuronal ablation, suggesting that GABAergic signaling in the PBN is important for the regulation of feeding ( $\mathrm{Wu}$ et al., 2009).

Recently, advanced technologies such as the optogenetic and DREADD (designer receptors exclusively activated by designer drugs) systems have provided stronger evidences on the central role of POMC and NPY/AgRP neurons in the regulation of feeding behavior (Aponte et al., 2011; Krashes et al., 2011, 2013; Atasoy et al., 2012; Zhan et al., 2013). For example, Zhan and collaborators recently showed that POMC neurons regulate feeding by integrating long-term information from the ARC and shortterm information from the NTS in the brainstem (Zhan et al., 2013). On the other hand, activation of AgRP neurons acutely promotes feeding behavior but suppression of POMC neurons is not required for this acute effect (Aponte et al., 2011; Krashes et al., 2011; Atasoy et al., 2012). One study, using DREADD system, has addressed the temporal effect of the acute activation of AgRP neurons on food intake in single, double or triple knockdown of NPY, AgRP-specific vesicular GABA transporter and MC4R (Krashes et al., 2013). This study proposes that NPY and GABA are required for the short-term feeding response while AgRP is responsible for the long-term feeding response.

$\alpha-\mathrm{MSH}$ and AgRP exert their metabolic effects through direct interaction with MCRs. In the CNS, MC3R, expressed in the hypothalamic arcuate POMC nucleus, and MC4R, expressed in several brain areas including the paraventricular nucleus of the hypothalamus, play a critical role in mediating the agonistic and antagonistic effect of $\alpha-\mathrm{MSH}$ and AgRP, respectively (Ollmann et al., 1997). Both MC3R and MC4R deficient mice displayed an obese phenotype, however, while MC3R are not hyperphagic (Butler et al., 2000; Chen et al., 2000; Renquist et al., 2012), MC4R deficiency mice show hyperphagia and reduced energy expenditure (Huszar et al., 1997; Marsh et al., 1999; Butler et al., 2001). In addition, mutations in the human MC4R gene are associated with non-syndromic obesity (Vaisse et al., 1998; Yeo et al., 1998).

The importance of MC4R-expressing neurons in the PVN in regulating metabolism has been recently showed by studies in which restoration of MC4Rs in PVN Single-minded 1 (SIM1) neurons of MC4Rs deficient mice induced a reduced obese phenotype (Xu et al., 2013; Shah et al., 2014). Of note, SIM1 seems to play also an important role in metabolism regulation both in humans and mice (Holder et al., 2000; Michaud et al., 2001).

The activity of the melanocortin neurons is regulated by many peripheral signals including hormones such as leptin, ghrelin, insulin, glucocorticoids, and thyroid hormones. By either activating or inhibiting these neurons, these peripheral signals convey information on the metabolic status of the organism.

\section{LEPTIN}

Leptin is an anorexigenic hormone produced and released by the white adipose tissue in the amount proportional to the mass of fat in the body (Zhang et al., 1994; Frederich et al., 1995; Maffei et al., 1995). Leptin interacts with six types of receptors (Ob-Ra, $-R b,-R c, R d, R e$, and $R f$ ) encoded by a single leptin receptor gene $(O b-R)$ (Lee et al., 1996; Wang et al., 1996). However, only the long form of leptin receptors $(O b-R b)$, consisting of an extracellular and an intact cytoplasmic domain, mediates the anorexigenic effect of leptin (De Luca et al., 2005). Deficiency in leptin or leptin receptors induces a morbid obese phenotype characterized by hyperphagia, hyperglycemia, hyperlipidemia, and reduced energy expenditure in both rodents and humans (Halaas et al., 1995; Chen et al., 1996; Montague et al., 1997; Clement et al., 1998). Neuron-specific Ob-R-deficient $(d b / d b)$ mice displayed an obese phenotype while hepatocyte-specific $d b / d b$ mice are normal (Cohen et al., 2001; De Luca et al., 2005), suggesting that the direct effect of leptin in the brain is essential for metabolism regulation. Mice lacking Ob-Rb in POMC neurons, AgRP neurons or both POMC/AgRP neurons displayed increased body weight and fat mass (Balthasar et al., 2004; Van De Wall et al., 2008), although their phenotypes are milder compared to those of whole brain neuron-specific $\mathrm{Ob}-\mathrm{Rb}$ deficient mice, suggesting the involvement of other leptin receptor-expressing neurons in mediating the effect of leptin on energy homeostasis.

Leptin regulates POMC and NPY/AgRP neurons at different levels. For examples, leptin increases POMC mRNA levels while decreasing NPY/AgRP mRNAs (Mizuno et al., 1998; Mizuno and Mobbs, 1999). Besides the transcriptional regulation, leptin directly depolarizes (activates) POMC neurons while simultaneously hyperpolarizing (inactivates) NPY/AgRP neurons (Cowley et al., 2001). In addition, systemic leptin administration to leptin deficient (ob/ob) mice rapidly induced synaptic input reorganization onto NPY/AgRP and POMC neurons (Pinto et al., 2004), suggesting that the synaptic rearrangement is an important event for leptin-induced behavioral changes (Horvath, 2006). A recent study demonstrated that AgRP neurons are critical in mediating metabolic syndrome in ob/ob mice since ablation of Agrp neurons in leptin deficient $(o b / o b)$ mice showed reduced food intake and improved glucose tolerance (Wu et al., 2012).

\section{INSULIN}

Insulin, produced from pancreatic $\beta$-cells, plays a fundamental role in the regulation of glucose homeostasis by modulating glucose uptake in peripheral organs (Bagdade et al., 1967). However, since insulin receptors (IR) are widely expressed in the brain (Havrankova et al., 1978), accumulated evidences have indicated a role for insulin in the CNS. Indeed, brain specific-IR deficient mice develop obesity with increased body weight, fat mass, and food intake (Bruning et al., 2000). However, mice with selective deletion of IR in the arcuate melanocortin system, either POMC or AgRP neurons, did not display alteration in energy homeostasis, while only a defective suppression on hepatic glucose production was found in mice with selective deletion of IR in AgRP neurons (Konner et al., 2007). In addition, reexpression of IR in either POMC or AgRP neurons of L1 mice, a genetic mouse model with significant reduction of IR in the 
ARC (Okamoto et al., 2004), suggested that insulin signaling in AgRP neurons negatively regulates hepatic glucose production while IR activation in POMC neurons positively regulates hepatic glucose production and energy expenditure (Lin et al., 2010). Interestingly, when both leptin and IR were ablated in POMC neurons, systemic insulin resistance despite increased pancreatic insulin secretion was observed in these mice (Hill et al., 2010). In addition, the obese phenotype observed in POMC-specific ObR knockout mice was ameliorated when both ObR and IR were selectively deleted from POMC neurons, suggesting that insulin and leptin signaling in POMC neurons may have opposing effects in the regulation of body weight but additive effects on glucose homeostasis. In support of this, leptin and insulin responsive neurons are expressed in distinct subpopulations of POMC neurons (Williams et al., 2010). Thus, the divergent effects of leptin and insulin on energy homeostasis may due to the activation of different POMC subpopulations.

\section{GHRELIN}

Ghrelin, the hunger hormone, is predominantly secreted by specialized endocrine cells of the stomach when the stomach is empty. Ghrelin is synthesized as a preprohormone and several processes are required to generate its active form. After removing the signal peptide from the preprohormone, ghrelin precursor is acylated at the third serine with n-octanoic acid by an enzyme called ghrelin o-acyltransferase (GOAT) (Gutierrez et al., 2008; Yang et al., 2008) and then it is cleaved by prohormone convertase $1 / 3$ to produce the active 28 -amino-acid acylated ghrelin (Zhu et al., 2006). Ghrelin exerts its orexigenic effects through the growth hormone secretagogue receptor (GHSR) (Sun et al., 2004). The physiological function of Ghrelin and GHSR on feeding has been demonstrated by ghrelin and GHSR deficient mice. Both ghrelin- and GHSR-deficient mice are resistant to high-fat diet-induced obesity but only when mice are exposed to the diet shortly after post-weaning and not in adulthood (Sun et al., 2003; Wortley et al., 2004, 2005; Zigman et al., 2005).

The strongest expression of GHSR has been observed in the hypothalamus (Willesen et al., 1999). This observation, together with ghrelin-induced high c-fos expression in the hypothalamus, indicated this site of the CNS as main site of ghrelin's action. In the ARC, GHSR is predominantly expressed in NPY/AgRP neurons. Accordingly, peripheral and central administration of ghrelin induced c-fos expression in NPY/AgRP neurons (Nakazato et al., 2001; Wang et al., 2002). In addition, ghrelin increases NPY and AgRP mRNA expression levels and the electrical activity of NPY/AgRP neurons (Kamegai et al., 2001; Shintani et al., 2001; Cowley et al., 2003; Seoane et al., 2003; Van Den Top et al., 2004). Although ghrelin inhibits POMC neuronal activity, no GHSR expression has been reported in POMC neurons (Willesen et al., 1999) thus suggesting that this inhibitory effect may be mediated by the activation of NPY/AgRP neurons. In addition, ghrelin positively regulates prolyl carboxypeptidase, the enzyme responsible for $\alpha$-MSH degradation (Kwon Jeong et al., 2013) thus further increasing the orexigenic tone. Ghrelin-induced food intake is mediated by NPY/AgRP neurons (Nakazato et al., 2001; Shintani et al., 2001; Chen et al., 2004). For example, administration of neutralizing antibodies or antagonists of both NPY and AgRP blunted the orexigenic effects of ghrelin. Consistently, ghrelin's effect on feeding is abolished in NPY/AgRP doubledeficient mice (Chen et al., 2004). NPY/AgRP neurons-mediated ghrelin's effect is evident in diet-induced obese mice (DIO). DIO mice show decreased expression of Npy and AgRP mRNA levels, decreased Goat mRNA levels in the stomach and decreased hypothalamic GHSR expression and they are ghrelin resistance (Briggs et al., 2010). Interestingly, while ghrelin resistance has been observed in DIO mice, $o b / o b$ mice retain their sensitivity to ghrelin, suggesting that elevated leptin levels may be involved in the development of ghrelin resistance. In support of this, a recent study showed that central leptin administration in $o b / o b$ mice induced ghrelin resistance (Briggs et al., 2014). AgRP-selective re-expression of GHSR in whole body of GHSRdeficient mice partially restores the orexigenic response to ghrelin (Wang et al., 2014). In addition, AgRP-specific vesicular GABA transporter knockout mice showed impaired ghrelin-mediated feeding response and impaired inhibitory postsynaptic potentials in POMC neurons, indicating that GABA release from AgRP neurons is an important mediator of ghrelin's effect on food intake (Tong et al., 2008). Of note, uncoupling protein 2 (UCP2) is a mediator of ghrelin's action on feeding behavior in both the hypothalamus and the ventrotegmental area (VTA). In Ucp2 deficient mice, intrahypothalamic administration of ghrelin showed a blunted effect on food intake and intra-VTA ghrelin injection also attenuated food intake (Andrews et al., 2008).

\section{THYROID HORMONES}

Thyroid hormones play an important role in metabolism regulation affecting nearly all the tissues in the body. Thyroxine (T4) produced by the thyroid gland is converted in target tissues in the active form of thyroid hormone, Triiodothyronine (T3), by a process called $5^{\prime}$ deiodination. Thyroid hormones affect metabolism acting on both food intake and energy expenditure (Vijayan and Mccann, 1977; Suzuki et al., 1982; Lin et al., 1983; Choi et al., 2002; Herwig et al., 2008; Klieverik et al., 2009). The hyperphagia, induced by increased thyroid hormones levels, is mediated by the CNS. Indeed, central T3 administration induced increased food intake by increasing and reducing NPY and POMC mRNA levels, respectively (Ishii et al., 2003). Changes in central T3 levels occur during different metabolic states (Van Haasteren et al., 1995). For example, elevated levels of T3 occur in the hypothalamus during starvation (Coppola et al., 2005, 2007). This increased T3 is due to the elevated activity of the enzyme responsible for the conversion of T4 in T3 (Diano et al., 1998). Similar to the effect of T3 in the brown adipose tissue in increasing uncoupling protein 1 (UCP1) activity, T3 in the hypothalamus regulates UCP2 levels, which in turn, will affect the activity of NPY/AgRP neurons and thus increase food intake. Via this signaling pathway involving NPY/AgRP neuronal activity, T3 is also responsible for fasting-induced suppression of TRH mRNA expression in the PVN (Coppola et al., 2005, 2007; Vella et al., 2011).

\section{GLUCOCORTICOIDS}

Glucocorticoids are known regulators of energy balance (Nieuwenhuizen and Rutters, 2008). For example, Cushing' syndrome, one pathology characterized by hypercortisolism, 
displays several symptoms including hypertension, insulin resistance, hyperglycemia as well as rapid weight gain (Hankin et al., 1977). Conversely, Addison's disease, condition of hypocortisolism, causes weight loss (Lovas and Husebye, 2007). Similarly, hypocortisolism induced by adrenalectomy (ADX) reduces food intake, fat stores and body weight (Dallman et al., 2004). Since $\mathrm{ACTH}$, which is generated from POMC-expressing cells in the pituitary gland, stimulates the production of glucocorticoids from the adrenals, pituitary POMC's effects on energy balance were addressed in neural-specific POMC deficient mice (Smart et al., 2006). Interestingly, increased glucocorticoids by re-expression of pituitary POMC in neural-specific POMC deficient mice exacerbates obesity with severe insulin resistance, suggesting that central POMC's role is not substituted by peripheral POMC (Smart et al., 2006). In further support of the role of glucocorticoids in the regulation of energy balance, many obese mouse models including diet-induced obesity and genetic mouse models were characterized by elevated corticosterone levels, and ADX to these mice has been shown to ameliorate their obese phenotype (Okada et al., 1993; Makimura et al., 2000). The mechanism by which ADX ameliorates obesity involves the CNS. For example, corticosterone has been shown to affect the hypothalamic melanocortin signaling by regulating POMC and AgRP mRNA expression in leptin-deficient mice (Makimura et al., 2000). In addition, studies from our group have shown that ADX directly influences neuronal activity of the arcuate POMC neurons by affecting the synaptic input organization of these neurons (Gyengesi et al., 2010). Furthermore, ADX has been reported to enhance leptin's effect on feeding by reducing the responsiveness of melanocortin receptors to its ligands (Drazen et al., 2003).

\section{CONCLUSIONS}

The hypothalamic melanocortin system is an integrative center in the regulation of energy balance. Numerous studies have shown that many peripheral signals including hormones can directly influence the activity of the hypothalamic melanocortin system. Besides hormones, other signals including nutrients such as glucose (Thorens, 2012), lipids (Lam et al., 2005; Moulle et al., 2014), and amino acids (Cota et al., 2006; Schwartz, 2013) also function as signal molecules for the melanocortin system.

All of these signals have been shown to regulate the melanocortin system via extracellular and intracellular morphological changes that will affect the activity levels of the different component of the system. These changes include synaptic input organization (Pinto et al., 2004; Zeltser et al., 2012), neuronglia interaction, and intracellular organelles alterations including mitochondrial and peroxisomal density and function (for review see Koch and Horvath, 2014).

In conclusion, further studies on the mechanisms controlling the melanocortin system are crucial to make advancement in our abilities to develop new therapies for the treatment of metabolic disorders.

\section{ACKNOWLEDGMENT}

This work was supported by NIH grants DK 097566 and we would like to thank the Science, Technology, and Research Scholars (STARS) program at Yale College.

\section{REFERENCES}

Andrews, Z. B., Liu, Z. W., Wallingford, N., Erion, D. M., Borok, E., Friedman, J. M., et al. (2008). UCP2 mediates ghrelin's action on NPY/AgRP neurons by lowering free radicals. Nature 454, 846-851. doi: 10.1038/nature07181

Aponte, Y., Atasoy, D., and Sternson, S. M. (2011). AGRP neurons are sufficient to orchestrate feeding behavior rapidly and without training. Nat. Neurosci. 14, 351-355. doi: 10.1038/nn.2739

Atasoy, D., Betley, J. N., Su, H. H., and Sternson, S. M. (2012). Deconstruction of a neural circuit for hunger. Nature 488, 172-177. doi: 10.1038/nature11270

Bagdade, J. D., Bierman, E. L., and Porte, D. Jr. (1967). The significance of basal insulin levels in the evaluation of the insulin response to glucose in diabetic and nondiabetic subjects. J. Clin. Invest. 46, 1549-1557. doi: 10.1172/JCI105646

Balthasar, N., Coppari, R., Mcminn, J., Liu, S. M., Lee, C. E., Tang, V., et al. (2004). Leptin receptor signaling in POMC neurons is required for normal body weight homeostasis. Neuron 42, 983-991. doi: 10.1016/j.neuron.2004.06.004

Briggs, D. I., Enriori, P. J., Lemus, M. B., Cowley, M. A., and Andrews, Z. B. (2010). Diet-induced obesity causes ghrelin resistance in arcuate NPY/AgRP neurons. Endocrinology 151, 4745-4755. doi: 10.1210/en.2010-0556

Briggs, D. I., Lockie, S. H., Benzler, J., Wu, Q., Stark, R., Reichenbach, A., et al. (2014). Evidence that diet-induced hyperleptinemia, but not hypothalamic gliosis, causes ghrelin resistance in NPY/AgRP neurons of male mice. Endocrinology 155, 2411-2422. doi: 10.1210/en.2013-1861

Bruning, J. C., Gautam, D., Burks, D. J., Gillette, J., Schubert, M., Orban, P. C., et al. (2000). Role of brain insulin receptor in control of body weight and reproduction. Science 289, 2122-2125. doi: 10.1126/science.289.5487.2122

Bumaschny, V. F., Yamashita, M., Casas-Cordero, R., Otero-Corchon, V., De Souza, F. S., Rubinstein, M., et al. (2012). Obesity-programmed mice are rescued by early genetic intervention. J. Clin. Invest. 122, 4203-4212. doi: 10.1172/JCI62543

Butler, A. A., Kesterson, R. A., Khong, K., Cullen, M. J., Pelleymounter, M. A., Dekoning, J., et al. (2000). A unique metabolic syndrome causes obesity in the melanocortin-3 receptor-deficient mouse. Endocrinology 141, 3518-3521. doi: 10.1210/endo.141.9.7791

Butler, A. A., Marks, D. L., Fan, W., Kuhn, C. M., Bartolome, M., and Cone, R. D. (2001). Melanocortin-4 receptor is required for acute homeostatic responses to increased dietary fat. Nat. Neurosci. 4, 605-611. doi: 10.1038/88423

Chen, A. S., Marsh, D. J., Trumbauer, M. E., Frazier, E. G., Guan, X. M., Yu, H., et al. (2000). Inactivation of the mouse melanocortin-3 receptor results in increased fat mass and reduced lean body mass. Nat. Genet. 26, 97-102. doi: $10.1038 / 79254$

Chen, H., Charlat, O., Tartaglia, L. A., Woolf, E. A., Weng, X., Ellis, S. J., et al. (1996). Evidence that the diabetes gene encodes the leptin receptor: identification of a mutation in the leptin receptor gene in $\mathrm{db} / \mathrm{db}$ mice. Cell 84, 491-495. doi: $10.1016 / S 0092-8674(00) 81294-5$

Chen, H. Y., Trumbauer, M. E., Chen, A. S., Weingarth, D. T., Adams, J. R., Frazier, E. G., et al. (2004). Orexigenic action of peripheral ghrelin is mediated by neuropeptide $Y$ and agouti-related protein. Endocrinology 145, 2607-2612. doi: 10.1210/en.2003-1596

Choi, Y. H., Hartzell, D., Azain, M. J., and Baile, C. A. (2002). TRH decreases food intake and increases water intake and body temperature in rats. Physiol. Behav 77, 1-4. doi: 10.1016/S0031-9384(02)00784-9

Clement, K., Vaisse, C., Lahlou, N., Cabrol, S., Pelloux, V., Cassuto, D., et al. (1998). A mutation in the human leptin receptor gene causes obesity and pituitary dysfunction. Nature 392, 398-401. doi: 10.1038/32911

Cohen, P., Zhao, C., Cai, X., Montez, J. M., Rohani, S. C., Feinstein, P., et al. (2001). Selective deletion of leptin receptor in neurons leads to obesity. J. Clin. Invest. 108, 1113-1121. doi: 10.1172/JCI200113914

Coppola, A., Hughes, J., Esposito, E., Schiavo, L., Meli, R., and Diano, S. (2005). Suppression of hypothalamic deiodinase type II activity blunts TRH mRNA decline during fasting. FEBS Lett. 579, 4654-4658. doi: 10.1016/j.febslet.2005.07.035

Coppola, A., Liu, Z. W., Andrews, Z. B., Paradis, E., Roy, M. C., Friedman, J. M., et al. (2007). A central thermogenic-like mechanism in feeding regulation: an interplay between arcuate nucleus T3 and UCP2. Cell Metab. 5, 21-33. doi: 10.1016/j.cmet.2006.12.002

Cota, D., Proulx, K., Smith, K. A., Kozma, S. C., Thomas, G., Woods, S. C., et al. (2006). Hypothalamic mTOR signaling regulates food intake. Science 312, 927-930. doi: 10.1126/science.1124147

Cowley, M. A., Pronchuk, N., Fan, W., Dinulescu, D. M., Colmers, W. F., and Cone, R. D. (1999). Integration of NPY, AGRP, and melanocortin signals in 
the hypothalamic paraventricular nucleus: evidence of a cellular basis for the adipostat. Neuron 24, 155-163. doi: 10.1016/S0896-6273(00)80829-6

Cowley, M. A., Smart, J. L., Rubinstein, M., Cerdan, M. G., Diano, S., Horvath, T. L., et al. (2001). Leptin activates anorexigenic POMC neurons through a neural network in the arcuate nucleus. Nature 411, 480-484. doi: 10.1038/35078085

Cowley, M. A., Smith, R. G., Diano, S., Tschop, M., Pronchuk, N., Grove, K. L., et al. (2003). The distribution and mechanism of action of ghrelin in the CNS demonstrates a novel hypothalamic circuit regulating energy homeostasis. Neuron 37, 649-661. doi: 10.1016/S0896-6273(03)00063-1

Dallman, M. F., La Fleur, S. E., Pecoraro, N. C., Gomez, F., Houshyar, H., and Akana, S. F. (2004). Minireview: glucocorticoids-food intake, abdominal obesity, and wealthy nations in 2004. Endocrinology 145, 2633-2638. doi: 10.1210/en.2004-0037

De Luca, C., Kowalski, T. J., Zhang, Y., Elmquist, J. K., Lee, C., Kilimann, M. W., et al. (2005). Complete rescue of obesity, diabetes, and infertility in $\mathrm{db} / \mathrm{db}$ mice by neuron-specific LEPR-B transgenes. J. Clin. Invest. 115, 3484-3493. doi: 10.1172/JCI24059

Diano, S., Naftolin, F., Goglia, F., and Horvath, T. L. (1998). Fasting-induced increase in type II iodothyronine deiodinase activity and messenger ribonucleic acid levels is not reversed by thyroxine in the rat hypothalamus. Endocrinology 139, 2879-2884.

Drazen, D. L., Wortman, M. D., Schwartz, M. W., Clegg, D. J., Van Dijk, G., Woods, S. C., et al. (2003). Adrenalectomy alters the sensitivity of the central nervous system melanocortin system. Diabetes 52, 2928-2934. doi: 10.2337/diabetes.52.12.2928

Elmquist, J. K., Elias, C. F., and Saper, C. B. (1999). From lesions to leptin: hypothalamic control of food intake and body weight. Neuron 22, 221-232. doi: 10.1016/S0896-6273(00)81084-3

Erickson, J. C., Clegg, K. E., and Palmiter, R. D. (1996). Sensitivity to leptin and susceptibility to seizures of mice lacking neuropeptide Y. Nature 381, 415-421. doi: $10.1038 / 381415 \mathrm{a} 0$

Frederich, R. C., Hamann, A., Anderson, S., Lollmann, B., Lowell, B. B., and Flier, J. S. (1995). Leptin levels reflect body lipid content in mice: evidence for diet-induced resistance to leptin action. Nat. Med. 1, 1311-1314. doi: 10.1038/nm1295-1311

Greenman, Y., Kuperman, Y., Drori, Y., Asa, S. L., Navon, I., Forkosh, O., et al. (2013). Postnatal ablation of POMC neurons induces an obese phenotype characterized by decreased food intake and enhanced anxiety-like behavior. Mol. Endocrinol. 27, 1091-1102. doi: 10.1210/me.2012-1344

Gropp, E., Shanabrough, M., Borok, E., Xu, A. W., Janoschek, R., Buch, T., et al. (2005). Agouti-related peptide-expressing neurons are mandatory for feeding. Nat. Neurosci. 8, 1289-1291. doi: 10.1038/nn1548

Gutierrez, J. A., Solenberg, P. J., Perkins, D. R., Willency, J. A., Knierman, M. D., Jin, Z., et al. (2008). Ghrelin octanoylation mediated by an orphan lipid transferase. Proc. Natl. Acad. Sci. U.S.A. 105, 6320-6325. doi: 10.1073/pnas.0800708105

Gyengesi, E., Liu, Z. W., D’agostino, G., Gan, G., Horvath, T. L., Gao, X. B., et al. (2010). Corticosterone regulates synaptic input organization of POMC and NPY/AgRP neurons in adult mice. Endocrinology 151, 5395-5402. doi: 10.1210/en.2010-0681

Halaas, J. L., Gajiwala, K. S., Maffei, M., Cohen, S. L., Chait, B. T., Rabinowitz, D., et al. (1995). Weight-reducing effects of the plasma protein encoded by the obese gene. Science 269, 543-546. doi: 10.1126/science.7624777

Hankin, M. E., Theile, H. M., and Steinbeck, A. W. (1977). An evaluation of laboratory tests for the detection and differential diagnosis of Cushing's syndrome. Clin. Endocrinol. 6, 185-196. doi: 10.1111/j.1365-2265.1977.tb03314.x

Havrankova, J., Roth, J., and Brownstein, M. (1978). Insulin receptors are widely distributed in the central nervous system of the rat. Nature 272, 827-829. doi: $10.1038 / 272827 \mathrm{a} 0$

Herwig, A., Ross, A. W., Nilaweera, K. N., Morgan, P. J., and Barrett, P. (2008). Hypothalamic thyroid hormone in energy balance regulation. Obes. Facts 1, 71-79. doi: $10.1159 / 000123428$

Hill, J. W., Elias, C. F., Fukuda, M., Williams, K. W., Berglund, E. D., Holland, W. L., et al. (2010). Direct insulin and leptin action on pro-opiomelanocortin neurons is required for normal glucose homeostasis and fertility. Cell Metab. 11, 286-297. doi: 10.1016/j.cmet.2010.03.002

Holder, J. L. Jr., Butte, N. F., and Zinn, A. R. (2000). Profound obesity associated with a balanced translocation that disrupts the SIM1 gene. Hum. Mol. Genet. 9, 101-108. doi: $10.1093 / \mathrm{hmg} / 9.1 .101$
Horvath, T. L. (2006). Synaptic plasticity in energy balance regulation. Obesity (Silver Spring) 14(Suppl. 5), 228S-233S. doi: 10.1038/oby.2006.314

Horvath, T. L., Bechmann, I., Naftolin, F., Kalra, S. P., and Leranth, C. (1997). Heterogeneity in the neuropeptide Y-containing neurons of the rat arcuate nucleus: GABAergic and non-GABAergic subpopulations. Brain Res. 756, 283-286. doi: 10.1016/S0006-8993(97)00184-4

Huszar, D., Lynch, C. A., Fairchild-Huntress, V., Dunmore, J. H., Fang, Q., Berkemeier, L. R., et al. (1997). Targeted disruption of the melanocortin-4 receptor results in obesity in mice. Cell 88, 131-141. doi: 10.1016/S00928674(00)81865-6

Ishii, S., Kamegai, J., Tamura, H., Shimizu, T., Sugihara, H., and Oikawa, S. (2003). Hypothalamic neuropeptide Y/Y1 receptor pathway activated by a reduction in circulating leptin, but not by an increase in circulating ghrelin, contributes to hyperphagia associated with triiodothyronine-induced thyrotoxicosis. Neuroendocrinology 78, 321-330. doi: 10.1159/000074885

Kamegai, J., Tamura, H., Shimizu, T., Ishii, S., Sugihara, H., and Wakabayashi, I. (2001). Chronic central infusion of ghrelin increases hypothalamic neuropeptide $\mathrm{Y}$ and Agouti-related protein mRNA levels and body weight in rats. Diabetes 50, 2438-2443. doi: 10.2337/diabetes.50.11.2438

Klieverik, L. P., Coomans, C. P., Endert, E., Sauerwein, H. P., Havekes, L. M., Voshol, P. J., et al. (2009). Thyroid hormone effects on whole-body energy homeostasis and tissue-specific fatty acid uptake in vivo. Endocrinology 150, 5639-5648. doi: 10.1210/en.2009-0297

Koch, M., and Horvath, T. L. (2014). Molecular and cellular regulation of hypothalamic melanocortin neurons controlling food intake and energy metabolism. Mol. Psychiatry 19, 752-761. doi: 10.1038/mp.2014.30

Konner, A. C., Janoschek, R., Plum, L., Jordan, S. D., Rother, E., Ma, X., et al. (2007). Insulin action in AgRP-expressing neurons is required for suppression of hepatic glucose production. Cell Metab. 5, 438-449. doi: 10.1016/j.cmet.2007.05.004

Krashes, M. J., Koda, S., Ye, C., Rogan, S. C., Adams, A. C., Cusher, D. S., et al. (2011). Rapid, reversible activation of AgRP neurons drives feeding behavior in mice. J. Clin. Invest. 121, 1424-1428. doi: 10.1172/JCI46229

Krashes, M. J., Shah, B. P., Koda, S., and Lowell, B. B. (2013). Rapid versus delayed stimulation of feeding by the endogenously released AgRP neuron mediators GABA, NPY, and AgRP. Cell Metab. 18, 588-595. doi: 10.1016/j.cmet.2013.09.009

Krude, H., Biebermann, H., Luck, W., Horn, R., Brabant, G., and Gruters, A. (1998). Severe early-onset obesity, adrenal insufficiency and red hair pigmentation caused by POMC mutations in humans. Nat. Genet. 19, 155-157. doi: $10.1038 / 509$

Krude, H., and Gruters, A. (2000). Implications of proopiomelanocortin (POMC) mutations in humans: the POMC deficiency syndrome. Trends Endocrinol. Metab. 11, 15-22. doi: 10.1016/S1043-2760(99)00213-1

Kwon Jeong, J., Dae Kim, J., and Diano, S. (2013). Ghrelin regulates hypothalamic prolyl carboxypeptidase expression in mice. Mol Metab 2, 23-30. doi: 10.1016/j.molmet.2013.01.002

Lam, T. K., Schwartz, G. J., and Rossetti, L. (2005). Hypothalamic sensing of fatty acids. Nat. Neurosci. 8, 579-584. doi: 10.1038/nn1456

Lee, G. H., Proenca, R., Montez, J. M., Carroll, K. M., Darvishzadeh, J. G., Lee, J. I., et al. (1996). Abnormal splicing of the leptin receptor in diabetic mice. Nature 379, 632-635. doi: 10.1038/379632a0

Lin, H. V., Plum, L., Ono, H., Gutierrez-Juarez, R., Shanabrough, M., Borok, E., et al. (2010). Divergent regulation of energy expenditure and hepatic glucose production by insulin receptor in agouti-related protein and POMC neurons. Diabetes 59, 337-346. doi: 10.2337/db09-1303

Lin, M. T., Chu, P. C., and Leu, S. Y. (1983). Effects of TSH, TRH, LH and LHRH on thermoregulation and food and water intake in the rat. Neuroendocrinology 37, 206-211. doi: 10.1159/000123544

Lovas, K., and Husebye, E. S. (2007). Continuous subcutaneous hydrocortisone infusion in Addison's disease. Eur. J. Endocrinol. 157, 109-112. doi: 10.1530/EJE07-0052

Luquet, S., Perez, F. A., Hnasko, T. S., and Palmiter, R. D. (2005). NPY/AgRP neurons are essential for feeding in adult mice but can be ablated in neonates. Science 310, 683-685. doi: 10.1126/science.1115524

Maffei, M., Halaas, J., Ravussin, E., Pratley, R. E., Lee, G. H., Zhang, Y., et al. (1995). Leptin levels in human and rodent: measurement of plasma leptin and ob RNA in obese and weight-reduced subjects. Nat. Med. 1, 1155-1161. doi: $10.1038 / \mathrm{nm} 1195-1155$ 
Makimura, H., Mizuno, T. M., Roberts, J., Silverstein, J., Beasley, J., and Mobbs, C. V. (2000). Adrenalectomy reverses obese phenotype and restores hypothalamic melanocortin tone in leptin-deficient ob/ob mice. Diabetes 49, 1917-1923. doi: 10.2337/diabetes.49.11.1917

Marsh, D. J., Hollopeter, G., Huszar, D., Laufer, R., Yagaloff, K. A., Fisher, S. L., et al. (1999). Response of melanocortin-4 receptor-deficient mice to anorectic and orexigenic peptides. Nat. Genet. 21, 119-122. doi: 10.1038/5070

Michaud, J. L., Boucher, F., Melnyk, A., Gauthier, F., Goshu, E., Levy, E., et al. (2001). Sim1 haploinsufficiency causes hyperphagia, obesity and reduction of the paraventricular nucleus of the hypothalamus. Hum. Mol. Genet. 10, 1465-1473. doi: 10.1093/hmg/10.14.1465

Mizuno, T. M., Kleopoulos, S. P., Bergen, H. T., Roberts, J. L., Priest, C. A., and Mobbs, C. V. (1998). Hypothalamic pro-opiomelanocortin mRNA is reduced by fasting and [corrected] in ob/ob and $\mathrm{db} / \mathrm{db}$ mice, but is stimulated by leptin. Diabetes 47, 294-297. doi: 10.2337/diab.47.2.294

Mizuno, T. M., and Mobbs, C. V. (1999). Hypothalamic agouti-related protein messenger ribonucleic acid is inhibited by leptin and stimulated by fasting. Endocrinology 140, 814-817.

Montague, C. T., Farooqi, I. S., Whitehead, J. P., Soos, M. A., Rau, H., Wareham, N. J., et al. (1997). Congenital leptin deficiency is associated with severe early-onset obesity in humans. Nature 387, 903-908. doi: 10.1038/43185

Moulle, V. S., Picard, A., Le Foll, C., Levin, B. E., and Magnan, C. (2014). Lipid sensing in the brain and regulation of energy balance. Diabetes Metab. 40, 29-33. doi: 10.1016/j.diabet.2013.10.001

Nakazato, M., Murakami, N., Date, Y., Kojima, M., Matsuo, H., Kangawa, K., et al. (2001). A role for ghrelin in the central regulation of feeding. Nature 409, 194-198. doi: 10.1038/35051587

Nieuwenhuizen, A. G., and Rutters, F. (2008). The hypothalamic-pituitary-adrenalaxis in the regulation of energy balance. Physiol. Behav. 94, 169-177. doi: 10.1016/j.physbeh.2007.12.011

Okada, S., Onai, T., Kilroy, G., York, D. A., and Bray, G. A. (1993). Adrenalectomy of the obese Zucker rat: effects on the feeding response to enterostatin and specific mRNA levels. Am. J. Physiol. 265, R21-R27.

Okamoto, H., Nakae, J., Kitamura, T., Park, B. C., Dragatsis, I., and Accili, D. (2004). Transgenic rescue of insulin receptor-deficient mice. J. Clin. Invest. 114, 214-223. doi: 10.1172/JCI200421645

Ollmann, M. M., Wilson, B. D., Yang, Y. K., Kerns, J. A., Chen, Y., Gantz, I., et al. (1997). Antagonism of central melanocortin receptors in vitro and in vivo by agouti-related protein. Science 278, 135-138. doi: 10.1126/science.278.5335.135

Pinto, S., Roseberry, A. G., Liu, H., Diano, S., Shanabrough, M., Cai, X., et al. (2004). Rapid rewiring of arcuate nucleus feeding circuits by leptin. Science 304, 110-115. doi: 10.1126/science.1089459

Qian, S., Chen, H., Weingarth, D., Trumbauer, M. E., Novi, D. E., Guan, X., et al. (2002). Neither agouti-related protein nor neuropeptide $\mathrm{Y}$ is critically required for the regulation of energy homeostasis in mice. Mol. Cell. Biol. 22, 5027-5035. doi: 10.1128/MCB.22.14.5027-5035.2002

Renquist, B. J., Murphy, J. G., Larson, E. A., Olsen, D., Klein, R. F., Ellacott, K. L., et al. (2012). Melanocortin-3 receptor regulates the normal fasting response. Proc. Natl. Acad. Sci. U.S.A. 109, E1489-E1498. doi: 10.1073/pnas.1201994109

Saito, M., Iwawaki, T., Taya, C., Yonekawa, H., Noda, M., Inui, Y., et al. (2001). Diphtheria toxin receptor-mediated conditional and targeted cell ablation in transgenic mice. Nat. Biotechnol. 19, 746-750. doi: 10.1038/90795

Schwartz, G. J. (2013). Central leucine sensing in the control of energy homeostasis. Endocrinol. Metab. Clin. North Am. 42, 81-87. doi: 10.1016/j.ecl.2012. 12.001

Seoane, L. M., Lopez, M., Tovar, S., Casanueva, F. F., Senaris, R., and Dieguez, C. (2003). Agouti-related peptide, neuropeptide Y, and somatostatin-producing neurons are targets for ghrelin actions in the rat hypothalamus. Endocrinology 144, 544-551. doi: 10.1210/en.2002-220795

Shah, B. P., Vong, L., Olson, D. P., Koda, S., Krashes, M. J., Ye, C., et al. (2014). MC4R-expressing glutamatergic neurons in the paraventricular hypothalamus regulate feeding and are synaptically connected to the parabrachial nucleus. Proc. Natl. Acad. Sci. U.S.A. 111, 13193-13198. doi: 10.1073/pnas.1407843111

Shintani, M., Ogawa, Y., Ebihara, K., Aizawa-Abe, M., Miyanaga, F., Takaya, K., et al. (2001). Ghrelin, an endogenous growth hormone secretagogue, is a novel orexigenic peptide that antagonizes leptin action through the activation of hypothalamic neuropeptide Y/Y1 receptor pathway. Diabetes 50, 227-232. doi: 10.2337/diabetes.50.2.227
Smart, J. L., Tolle, V., and Low, M. J. (2006). Glucocorticoids exacerbate obesity and insulin resistance in neuron-specific proopiomelanocortin-deficient mice. J. Clin. Invest. 116, 495-505. doi: 10.1172/JCI25243

Sun, Y., Ahmed, S., and Smith, R. G. (2003). Deletion of ghrelin impairs neither growth nor appetite. Mol. Cell. Biol. 23, 7973-7981. doi: 10.1128/MCB.23.22.7973-7981.2003

Sun, Y., Wang, P., Zheng, H., and Smith, R. G. (2004). Ghrelin stimulation of growth hormone release and appetite is mediated through the growth hormone secretagogue receptor. Proc. Natl. Acad. Sci. U.S.A. 101, 4679-4684. doi: 10.1073/pnas.0305930101

Suzuki, T., Kohno, H., Sakurada, T., Tadano, T., and Kisara, K. (1982). Intracranial injection of thyrotropin releasing hormone (TRH) suppresses starvationinduced feeding and drinking in rats. Pharmacol. Biochem. Behav. 17, 249-253. doi: 10.1016/0091-3057(82)90078-8

Thorens, B. (2012). Sensing of glucose in the brain. Handb. Exp. Pharmacol. 209, 277-294. doi: 10.1007/978-3-642-24716-3_12

Tong, Q., Ye, C. P., Jones, J. E., Elmquist, J. K., and Lowell, B. B. (2008). Synaptic release of GABA by AgRP neurons is required for normal regulation of energy balance. Nat. Neurosci. 11, 998-1000. doi: 10.1038/nn.2167

Vaisse, C., Clement, K., Guy-Grand, B., and Froguel, P. (1998). A frameshift mutation in human MC4R is associated with a dominant form of obesity. Nat. Genet. 20, 113-114. doi: 10.1038/2407

Van Den Top, M., Lee, K., Whyment, A. D., Blanks, A. M., and Spanswick, D. (2004). Orexigen-sensitive NPY/AgRP pacemaker neurons in the hypothalamic arcuate nucleus. Nat. Neurosci. 7, 493-494. doi: 10.1038/nn1226

Van De Wall, E., Leshan, R., Xu, A. W., Balthasar, N., Coppari, R., Liu, S. M., et al. (2008). Collective and individual functions of leptin receptor modulated neurons controlling metabolism and ingestion. Endocrinology 149, 1773-1785. doi: 10.1210/en.2007-1132

Van Haasteren, G. A., Linkels, E., Klootwijk, W., Van Toor, H., Rondeel, J. M., Themmen, A. P., et al. (1995). Starvation-induced changes in the hypothalamic content of prothyrotrophin-releasing hormone (proTRH) mRNA and the hypothalamic release of proTRH-derived peptides: role of the adrenal gland. J. Endocrinol. 145, 143-153. doi: 10.1677/joe.0.1450143

Vella, K. R., Ramadoss, P., Lam, F. S., Harris, J. C., Ye, F. D., Same, P. D., et al. (2011). NPY and MC4R signaling regulate thyroid hormone levels during fasting through both central and peripheral pathways. Cell Metab. 14, 780-790. doi: 10.1016/j.cmet.2011.10.009

Vijayan, E., and Mccann, S. M. (1977). Suppression of feeding and drinking activity in rats following intraventricular injection of thyrotropin releasing hormone (TRH). Endocrinology 100, 1727-1730. doi: 10.1210/endo-100-6-1727

Wang, L., Saint-Pierre, D. H., and Tache, Y. (2002). Peripheral ghrelin selectively increases Fos expression in neuropeptide $\mathrm{Y}$ - synthesizing neurons in mouse hypothalamic arcuate nucleus. Neurosci. Lett. 325, 47-51. doi: 10.1016/S03043940(02)00241-0

Wang, M. Y., Zhou, Y. T., Newgard, C. B., and Unger, R. H. (1996). A novel leptin receptor isoform in rat. FEBS Lett. 392, 87-90. doi: 10.1016/00145793(96)00790-9

Wang, Q., Liu, C., Uchida, A., Chuang, J. C., Walker, A., Liu, T., et al. (2014). Arcuate AgRP neurons mediate orexigenic and glucoregulatory actions of ghrelin. Mol. Metab. 3, 64-72. doi: 10.1016/j.molmet.2013.10.001

Willesen, M. G., Kristensen, P., and Romer, J. (1999). Co-localization of growth hormone secretagogue receptor and NPY mRNA in the arcuate nucleus of the rat. Neuroendocrinology 70, 306-316. doi: 10.1159/000054491

Williams, K. W., Margatho, L. O., Lee, C. E., Choi, M., Lee, S., Scott, M. M., et al. (2010). Segregation of acute leptin and insulin effects in distinct populations of arcuate proopiomelanocortin neurons. J. Neurosci. 30, 2472-2479. doi: 10.1523/JNEUROSCI.3118-09.2010

Wortley, K. E., Anderson, K. D., Garcia, K., Murray, J. D., Malinova, L., Liu, R., et al. (2004). Genetic deletion of ghrelin does not decrease food intake but influences metabolic fuel preference. Proc. Natl. Acad. Sci. U.S.A. 101, 8227-8232. doi: 10.1073/pnas.0402763101

Wortley, K. E., Del Rincon, J. P., Murray, J. D., Garcia, K., Iida, K., Thorner, M. O., et al. (2005). Absence of ghrelin protects against early-onset obesity. J. Clin. Invest. 115, 3573-3578. doi: 10.1172/JCI26003

Wu, Q., Boyle, M. P., and Palmiter, R. D. (2009). Loss of GABAergic signaling by AgRP neurons to the parabrachial nucleus leads to starvation. Cell 137, 1225-1234. doi: 10.1016/j.cell.2009.04.022 
Wu, Q., and Palmiter, R. D. (2011). GABAergic signaling by AgRP neurons prevents anorexia via a melanocortin-independent mechanism. Eur. J. Pharmacol. 660, 21-27. doi: 10.1016/j.ejphar.2010.10.110

Wu, Q., Whiddon, B. B., and Palmiter, R. D. (2012). Ablation of neurons expressing agouti-related protein, but not melanin concentrating hormone, in leptindeficient mice restores metabolic functions and fertility. Proc. Natl. Acad. Sci. U.S.A. 109, 3155-3160. doi: 10.1073/pnas.1120501109

Xu, Y., Wu, Z., Sun, H., Zhu, Y., Kim, E. R., Lowell, B. B., et al. (2013). Glutamate mediates the function of melanocortin receptor 4 on Siml neurons in body weight regulation. Cell Metab. 18, 860-870. doi: 10.1016/j.cmet.2013.11.003

Yang, J., Brown, M. S., Liang, G., Grishin, N. V., and Goldstein, J. L. (2008). Identification of the acyltransferase that octanoylates ghrelin, an appetitestimulating peptide hormone. Cell 132, 387-396. doi: 10.1016/j.cell.2008.01.017

Yaswen, L., Diehl, N., Brennan, M. B., and Hochgeschwender, U. (1999). Obesity in the mouse model of pro-opiomelanocortin deficiency responds to peripheral melanocortin. Nat. Med. 5, 1066-1070. doi: 10.1038/12506

Yeo, G. S., Farooqi, I. S., Aminian, S., Halsall, D. J., Stanhope, R. G., and O'rahilly, S. (1998). A frameshift mutation in MC4R associated with dominantly inherited human obesity. Nat. Genet. 20, 111-112. doi: 10.1038/2404

Zeltser, L. M., Seeley, R. J., and Tschop, M. H. (2012). Synaptic plasticity in neuronal circuits regulating energy balance. Nat. Neurosci. 15, 1336-1342. doi: $10.1038 / \mathrm{nn} .3219$

Zhan, C., Zhou, J., Feng, Q., Zhang, J. E., Lin, S., Bao, J., et al. (2013). Acute and long-term suppression of feeding behavior by POMC neurons in the brainstem and hypothalamus, respectively. J. Neurosci. 33, 3624-3632. doi: 10.1523/JNEUROSCI.2742-12.2013
Zhang, Y., Proenca, R., Maffei, M., Barone, M., Leopold, L., and Friedman, J. M. (1994). Positional cloning of the mouse obese gene and its human homologue. Nature 372, 425-432. doi: 10.1038/372425a0

Zhu, X., Cao, Y., Voogd, K., and Steiner, D. F. (2006). On the processing of proghrelin to ghrelin. J. Biol. Chem. 281, 38867-38870. doi: 10.1074/jbc.M607 955200

Zigman, J. M., Nakano, Y., Coppari, R., Balthasar, N., Marcus, J. N., Lee, C. E., et al. (2005). Mice lacking ghrelin receptors resist the development of diet-induced obesity. J. Clin. Invest. 115, 3564-3572. doi: 10.1172/JCI26002

Conflict of Interest Statement: The authors declare that the research was conducted in the absence of any commercial or financial relationships that could be construed as a potential conflict of interest.

Received: 03 October 2014; accepted: 24 November 2014; published online: 09 December 2014.

Citation: Kim JD, Leyva S and Diano S (2014) Hormonal regulation of the hypothalamic melanocortin system. Front. Physiol. 5:480. doi: 10.3389/fphys.2014.00480

This article was submitted to Integrative Physiology, a section of the journal Frontiers in Physiology.

Copyright (c) 2014 Kim, Leyva and Diano. This is an open-access article distributed under the terms of the Creative Commons Attribution License (CC BY). The use, distribution or reproduction in other forums is permitted, provided the original author(s) or licensor are credited and that the original publication in this journal is cited, in accordance with accepted academic practice. No use, distribution or reproduction is permitted which does not comply with these terms. 